DOI 10.2478/auseb-2021-0009

\title{
Corporate Board of Directors' Attributes and Audit Fees
}

\author{
Wasiu Abiodun SANYAOLU \\ Department of Accounting, University of Benin, Benin city, Edo State, Nigeria \\ Abbeysanyaolu15@yahoo.com
Abiola Mukaila TONADE
Department of Accounting, Crescent University, Abeokuta, Ogun State, Nigeria akanbitonade@yahoo.com
Babatunde Titus ADEJUMO \\ Director General, Debt Management Office, State of Osun, Abere, Nigeria \\ babatundeadejumo@yahoo.com
}

\begin{abstract}
This study examines the effect of corporate board of directors' attributes on audit fees for Nigerian listed Deposit Money Banks (DBMS). The study adopts an ex post facto research design and uses data on 10 deposit money banks sampled via purposive sampling technique using data spanning from 2012 to 2018. Results based on Generalized Method of Moment show that corporate board of directors' proxies do not significantly influence audit fees of Nigerian deposit money banks. However, firm size and profitability are found to affect external audit fee significantly. The study therefore concludes that corporate boards of directors' attributes do not individually significantly affect audit fees in Nigerian listed Deposit Money Banks. Arising from the findings, it is recommended that corporate governance practices should be strengthened so as to aid external audit.
\end{abstract}

Keywords: board size, board independence, board diligence, audit fee and GMM

JEL Classification: G38; M42

\section{Introduction}

This study examines whether corporate board of directors' attributes drive audit fees in Nigerian Deposit Money Banks (DBMs). The choice of financial sector by the study is informed by its contributions to the whole economy. The significance of the financial sector in any economy cannot be overemphasized. The sector is known to serve as the lubricant, which facilitates the smooth running of any 
economy (Yaqub and Omobitan, 2012). The linkage between the financial sector and economic growth has been a subject of discussion for a long time (Kurawa and Garba, 2014); it is, however, established that the sector is expected to galvanize economies by mobilizing funds from surplus to deficit ends, manage the payment systems and facilitate the effectiveness of monetary policies (Yaqub and Omobitan, 2012). Relying on his findings from a study focusing on sub-Saharan African countries, Ndebbio (2004) establishes that a developed financial sector triggers sustainable economic growth. Using England's economy as an example, Hicks (1969) also affirms that a well-developed financial sector engenders sustainable economic growth.

Undoubtedly, the Nigerian financial sector presents an ideal model of the financial sector of a developing economy. This is so given that the country's financial sector, like any other developing economy's financial sector, has a lessdeveloped capital market, which indicates the nation's inability to fully tap into the huge opportunities of capital accretion internally and into the huge potentials of foreign direct investments that a developed capital market offers. The limitation of most developing economies in this regard is mainly responsible for their low capital formation, unemployment, poor gross domestic product, low per capita income, and, finally, poor standard of living in general. Studies focusing on factors that could further strengthen the financial sectors of these climates will expectedly provide insights on what to do to address some of the economic plagues confronting these economies, and, therefore, these will prove to be a worthwhile endeavour.

Businesses around the world need to be able to attract funding from investors in order to expand and grow (Mallin, 2011). Investors, however, require a certain level of assurances concerning the safety of their funds as well as the expected returns thereon. These assurances are usually and traditionally derived from disclosures made about business status in companies' annual financial statements, duly attested by an independent person (auditor).

While corporate governance, of which the board of directors is an integral part, remains on the front burner of all business entities owing to its numerous benefits - particularly on strengthening corporate harmony -, external audit remains one of its key mechanisms. The contribution of external audit to the various stakeholders of business organizations in terms of deepening their confidence in relation to the safety of their interests (financial and non-financial) and investments is the reason it maintains a vantage position within the corporate governance domain. As the need for financial statements' integrity increases, companies are under pressure to ensure quality audits. A quality audit carried out by reputable audit firms, however, constitutes part of firms' operating costs, which in effect reduces companies' bottom line in terms of profitability. One of the ways the cost of external audit can be reduced, however, is by reducing the number of areas of concern and internal control deficiency that the audit firm needs to verify. 
Poor bank governance negatively affects the economy and the society. Strong corporate governance mechanisms and external audit are of significant relevance to shareholders and customers as well as to regulators for the protection of their reputation and to ensure public confidence (Jizi and Nehme, 2018). Separation of ownership from management further reiterates the need for the professional examination of financial statements to ensure that they show a true and fair view of the entity's financial affairs. Audits, therefore, play a unique role in reducing agency problem by serving as the tool for aligning the interests of the agents with that of the principals (Jensen and Mecling, 1976). Audits strengthen the quality of financial reporting and thus assist in reducing information asymmetry and guarantee equal treatment of all shareholders in a way that mitigates agency problems (Desender, Aguilera, Crespi, and Garcia-Cestona, 2013). Audit fee is regarded by Liu (2017) as economic remuneration paid to auditors as a reward for audit services, which serves as an agency fee. He argues further that the fee paid is the combination of the total cost of audit through the overall audit work, the risk compensation, and the profit demand.

It is reasoned in the literature that effective CG practices should ordinarily strengthen internal control effectiveness, in effect, minimize the areas of concern for the external auditor and possibly reduce the cost of such audit exercise; CG and audit fees have in recent time attracted researchers' interest, and many empirical investigations have been attempted in this regard. The unending debate on the topic has, however, been sustained as a result of corporate scandals of the world's most reckoned with entities such as Adelphia, WorldCom, Enron, and Parmalat (Farooq, Kazim, Usman, and Latif, 2018; Ilaboya and Obaretin, 2015). Besides these debates, these corporate scandals have also raised the concern of the stakeholders about the issue of the effectiveness of corporate governance and external audit as control tools for mitigating the pervasiveness of agency problems.

Additionally, the Nigerian banking sector has witnessed a series of corporate scandals that have generated the failure of many banks, arising from weak corporate governance and failure of external audit to provide the necessary assurance service. In line with this, a series of reforms aimed at improving the corporate governance structure have been introduced by the appropriate banks' regulatory bodies in Nigeria. Despite the reforms, the issue of corporate governance failure still persists. For instance, the failure of Skye Bank in this context is significantly linked to corporate governance failure.

Corporate board of directors refers to one of the corporate governance structures designed to run and direct the affairs of an entity in order to safeguard the interests of the business stakeholders. Larcker and Tayan (2011) view corporate governance itself as a control process designed by an entity to prevent its agents from actions considered detrimental to the achievement of its desired goals, and by so doing ensure its going concern. The importance of strong corporate governance was 
further brought to the front burner after the failure of some world-class entities such as Adelphia, WorldCom, Enron, and Parmalat (Farooq et al., 2018). In the Nigerian banking sector, for instance, a series of corporate failures involving banks such as Oceanic Bank, Intercontinental Bank, Savannah Bank, Afribank, etc. has been significantly linked to the failure of governance structure and external audit. This development further directed the attention of banks' regulators to the issue of corporate governance, which has thus driven the Central Bank of Nigeria and Security and Exchange Commission to develop a corporate code of conduct for DBMs and discount houses in a bid to ensure the proper discharge of directors' responsibility for financial transparency and accountability. According to Dabor and Dabor (2015), corporate governance is regarded as one of the tools for enhancing financial reporting quality and its reliability. Zaman, Hudaib, and Haniffa (2011) argued that board of directors and audit committee effectiveness is likely to protect auditors' independence and reduce the probability of issuing inaccurate audit opinions on top management's polices.

Though external audit has been established as one of the key mechanisms of CG, discussions on the significance of their nexus is yet to be laid to rest. Two paradigms exist in literature as regards the association between CG and audit fees. The first line of thought is synthesised from substitution theory, while the second line of argument rests on signalling theory. The two paradigms, however, due to their different theoretical underpinnings, produce conflicting empirical outcomes (Wu, 2012). On the one hand, substitution theory argues that effective corporate governance practices are a substitute for external audit service. Accordingly, strong internal control practices are associated with lower agency costs and risk for audit firms, which in turn suggest lower audit effort and, hence, lower audit fees (Wu, 2012). On the other hand, the signal sent by deficient corporate governance practices to external auditors warrants managers to engage the services of highquality audit firms, which in effect leads to high audit fees (Wu, 2012).

To the best of our knowledge, studies on corporate board of directors' attributes and audit fees are scanty and call for empirical investigation focusing on the key roles played by corporate governance and external audit, towards ensuring the proper functioning of banks as well as transparency, accountability, and protection of shareholders' interest. As gleaned from extant studies, most studies on corporate board of directors' attributes and external audit in Nigerian banks have mainly focused on corporate governance and audit firm choice (see: Soyemi, 2020; Ilaoya, 2014; Ejeagbasi, Nweze, Ezeh, and Nze, 2015) and the determinants of audit fees (Ezinand, 2020; Monsuru, 2014). Some studies have examined the influence of CG on external auditors' reporting lag (see: Soyemi, Sanyaolu, and Salawu, 2019; Ilaboya and Iyafekhe, 2014; Salau and Ayoib, 2016). With a view to expanding the horizon of the extant effort, therefore, this study examines in its dynamic form the relationship between CG and audit fees, focusing specifically on the financial 
sector, a critical sector in any economy. The main objective is to investigate in its dynamic form, using data covering a period of seven years (2012-2018), the nexus between the corporate board of directors' attributes and the external audit fees of Nigerian DBMs as to whether it plays a substitutive or complementary role in influencing external audit fees.

In this study, three critical aspects of corporate board of directors' attributes are operationalized. These are board size, board independence, and board diligence (measured in terms of frequency of meetings). In line with the variables, three hypotheses are also developed regarding the corporate board of directors' attributes and audit fees. Our empirical findings show that boards of larger size and frequent meetings are associated with higher audit fees, while highly independent boards show positive effect on audit fees, implying that board independence increases audit fees.

We adopted the approach of Jizi and Nehme (2018) by examining the effect of corporate board of directors' attributes on audit fees, and we also highlight the policy implications of the study's findings for the deposit money banks and their regulatory authorities.

The practical implications of our finding imply that good governance is an essential component of quality audit as the later tends to yield good financial reporting quality, which in turn assists in reducing asymmetry information and supports the efficient functioning of the financial market. The study provides insights into policies that are interested in enhancing the financial aspect of corporate governance in order to achieve an improved financial reporting. Therefore, the study can provide a useful tool for practitioners and policy makers with regard to the critical roles of effective corporate governance mechanisms, which in turn can help in reducing market imperfections that hinder the efficient functioning of financial market, specifically of the banking sector.

The remaining of this paper is structured as follows. Section 2 focuses on the review of literature. Section 3 addresses methodology. Results and the discussion of findings are presented in Section 4, while Section 5 concludes and makes recommendations and suggestions for further investigations.

\section{Conceptual Review}

\section{Board Size and Audit Fee}

The effect of board size on board monitoring and control has generated controversy in literature. Basically, two strands of argument exist concerning board size, board monitoring, and control effectiveness. Some scholars have argued that small board size brings better governance as they believe that small firms are better able to 
monitor and control their activities considering the better communication and level of interaction they enjoy (Ozkan, 2007). By contrast, Lipton and Lorsch (1992) and Jensen (1993) argued for a larger board, indicating that it helps in better monitoring, considering the diverse expertise and the varied experience of the board members. Their argument is that larger boards are more motivated to ensure the credibility of financial reporting and thus opt for quality audit firms that may charge high audit fees. Studies such as Bozec and Dia (2017), Jizi and Nehme (2018), and Karim et al. (2015) have documented the direct influence of board size on AF. We, therefore, hypothesise that board size has no significant positive effect on external audit fees of Nigerian listed DBMs.

\section{Board Independence and Audit Fees}

Non-executive directors are saddled with the responsibility of monitoring top managers so as to protect the interest of the shareholders against the management's opportunistic behaviour (Farooq et al., 2018). Directors with non-executive status are considered highly essential as they act as check and balance on the management due to their non-involvement in the daily business affairs of the entity. The level of independence they enjoy further propels them towards taking independent courses of actions that are considered beneficial to the protection and maximization of shareholders' wealth. In support of this argument, prior studies have reported the positive effect of board independence on audit fees as board independence may entail audit quality so as to improve assurance and confidence (Bozec and Dia, 2017; Jizi and Nehme, 2018). With a view to investigating this in the domain of the current study, we hypothesise that board independence has no significant positive effect on external audit fees of Nigerian listed DBMs.

\section{Board Diligence and Audit Fees}

Board diligence in this study refers to the extent of board activities in terms of the frequency of their meetings in a fiscal year. Lara et al. (2009) regarded board diligence as a strong measure of board monitoring as it depicts the extent of board monitoring and control functions. The frequency of board meetings is considered by Lipton and Lorsch (1992) to be associated with the better performance of duties in a diligent manner, which is considered beneficial to the interest of the shareholders. In support of the argument, Vifeas (1999) indicated that the frequency of board meetings is related to the effectiveness of board oversight. According to Farooq et al. (2018), board diligence may enhance the credibility of the financial statement. Carcello and Neal (2000) expressed this succinctly by stating that a high level of board diligence may warrant the service of high-quality auditor so as to attain high level of assurance, which may ultimately lead to high audit fees. 
This study, however, consequently hypothesises that board diligence has no significant positive effect on external audit fees of Nigerian listed DBMs.

\section{Theoretical Review}

Studies of CG and external audit have hovered around some theories prominent among which are: agency theory, signalling theory, and lending credibility theory.

The agency theory was developed by Jensen and Meckling (1976) to capture the agency crisis between the agents and the principals as a result of ownership being separated from management. Shareholders employ managers to run the affairs of their entity. Agency crisis sets in due to shareholders' inability to directly monitor the behaviour of the managers (Jensen and Meckling, 1976). To further provide a control mechanism, shareholders incur agency cost such as audit fee. The auditor as shareholders' agent acts in such capacity by conducting an independent examination on the financial statements prepared by the management before the final presentation to the shareholders. This assists in reducing asymmetric information and thus lends more credence to the financial reports. In an entity with a pervasive agency crisis, more audit time, resources, and efforts will be required. This invariably increases audit fees (Leventis et al., 2005). The signalling theory opines that the outcome of the external audit services sends signal to the market about the credibility of the financial statement. The fees paid to the auditor are therefore a significant factor in determining the level of the audit quality. A high-quality audit, of course, sends positive signals to the market. This implies that users of such financial statements tend to ascribe more credibility to such financial statements. It could therefore be argued that the overall purpose of external audit is to attest to the credibility of financial statements so as to enhance the confidence of its users.

This study, therefore, significantly relies on agency theory, which postulates that in order to reduce agency problems, shareholders incur agency costs such as audit fees so as to monitor the management with a view to reducing the agency costs that they are exposed to.

\section{Empirical Review}

Applying regression analysis on the data of 19 randomly selected banks in Nigeria, Akhidime (2015) found a positive influence of non-executive directors, while independent directors and directors sharing ownership on audit quality were found to have a negative effect on audit quality. Using regression analysis on the data of 11 Nigerian listed DBMs from 2007 to 2014, Ejeagbasi et al. (2015) found that CEO function separation, board size, and audit committee composition significantly and directly influence audit quality, while board independence was found to have negative and insignificant effect. 
Farooq et al. (2018) analysed the impact of CG on audit fee using 5 years data of Pakistani quoted companies. Findings obtained from the regression analysis show that surrogates for corporate governance have positive influence on external audit fees.

Kikhia (2014) found from his investigation on a sample of 112 Jordanian nonfinancial firms from 2010 to 2012 that board independence, expertise, and size exert positive significant influence on audit fees.

In an investigation on the effect of overconfident managers on audit fees with board characteristics as moderating variables, Mitra, Jaggi, and Al-Hayale (2019) found that there was a significant and direct influence of overconfident managers on audit quality. It was also found that board characteristics directly influence the nexus of overconfidence of managers and audit fees.

Focusing on small firms in America and New Zealand, Ananthanarayanan (2018) established that short-term incentive total compensation influences audit risk, thus increasing audit risk. It was further established that good corporate governance is associated with audit quality, which in turn warrants higher audit fees.

Kee (2015) examined the influence of audit committees on Malaysian Public Companies using 4,570 firms from the period from 2003 to 2012. The study found no significant influence of audit committee attributes on audit fees.

Using data on 379 of Malaysian quoted firms from 1999 to 2002, Effiezal, Mazlina, and Kieran (2011) found evidence for the significant positive effect of CG on audit fees.

In a study using regression analysis and carried out in Nigeria based on the data obtained from the annual reports of 15 DBMs from 2009 to 2018, Ezinando (2020) found evidence to suggest that audit fees are not positively and significantly determined by client size, client complexity, and the independence of audit committee. Kim, Emma-Riikka, and Per (2018) established that there was a significantly negative effect of alumnus chair of the audit committee on audit fees. However, it was found to have positive influence on non-audit fees as a proportion of total fees charged by an external auditor. Using panel regression analysis on a sample of quoted Canadian companies from 2002 to 2008, Bozec and Dia (2017) investigated the effect of board characteristics on audit fees with ownership structure as moderator. The result of the regression analysis reveals that board independence (BI) when moderated with high ownership concentration has a significant positive effect on audit fees.

Jizi and Nehme (2018) used regression analysis involving fixed effect on a sample of US national commercial banks with 664 firm year observations for seven years. Findings reveal that board size, the CEO/chair dual role, and audit committee financial experts positively influence audit fees. Karim, Robin, and Suh (2015) reported an indirect association between audit fees and overlapping of audit committees and that board classification is directly associated with audit fees. 


\section{Methodology}

\subsection{Sample}

The sample of the study is made up of purposively selected 10 listed DBMs. As at 31 December 2018, 15 DBMs were listed on the Nigerian stock exchange. The selected 10 banks represent $67 \%$ of the entire list. The purposive sampling technique is adopted in this study, and the applicable research design is ex post facto. The choice of this research design is informed by the fact that the data of the study relate to past event, and as such it cannot be manipulated by the researcher.

\subsection{Source of Data}

Data for the selected 10 banks were sourced from their financial statements from the period of 2012-2018. The financial statements were obtained from the website of the selected banks and from the Nigerian stock exchange yearly fact books.

\subsection{Measurement of Variables}

Audit fee is the only dependent variable of the study, which represents the total fee paid to the external auditor or the external audit exercise, as reported in their FS for the period under consideration. For ease of measurement, this study also used natural logarithm of total audit fee as used by prior researchers such as Farooq et al. (2018), Ghafran and O'Sullivan (2017), and Jizi and Nehme (2018). We use three variables to proxy the corporate board of directors' attributes. The first variable is board size, which is the total number of directors on the board. The second variable is board independence proxied by the proportion of non-executive directors to total directors on the board. The third variable is board diligence, a measure of total board activities in terms of the frequency of board of directors' meetings for the years under coverage.

In addition, the studied firm's size measured by logarithm of total assets and profitability is measured in terms of natural logarithm of profit before tax as control variables. This approach is in line with that of Jizi and Nehme (2018).

\subsection{Method of Data Analysis}

The study analysed the data by using inferential statistics by adopting descriptive and correlation analysis as well as generalized method of moment with the aid of EViews 9. The generalized method of moment is the preferred approach when the number of observations $(\mathrm{N})$ is greater than times series $(\mathrm{T})$. 


\subsection{Model Specification}

We specify the econometric model as follows:

$$
\mathrm{AUF}_{\mathrm{it}}=\beta_{0}+\beta_{1} \mathrm{AUF}_{\mathrm{it}-1}+\beta_{2} \mathrm{BS}_{\mathrm{it}}+\beta_{3} \mathrm{BI}_{\mathrm{it}}+\beta_{4} \mathrm{BD}_{\mathrm{it}}+\beta 4 \mathrm{ROA}_{\mathrm{it}}+\beta 4 \mathrm{FSZ}_{\mathrm{it}}+\mathrm{e}_{\mathrm{it}} \text {, }
$$

where $\mathrm{AUF}_{\text {it }}$ denotes the audit fee of firm $\mathrm{i}$ in period $\mathrm{t}, \mathrm{AUF}_{\mathrm{it}-1}$ denotes the previous year's audit fee, $\mathrm{BS}_{\mathrm{it}}$ denotes board size $\mathrm{f}$ firm in period $\mathrm{t}, \mathrm{BI}_{\mathrm{it}}$ denotes the board independence of firm $\mathrm{i}$ in period $\mathrm{t}, \mathrm{BD}_{\mathrm{it}}$ denotes board diligence of firm $\mathrm{i}$ in period $\mathrm{t}, \mathrm{ROA}_{\mathrm{it}}$ denotes return on asset of firm $\mathrm{i}$ in period $\mathrm{t}, \mathrm{FSZ}_{\mathrm{it}}$ denotes firm size of firm $i$ in period $t$, and $e_{i t}$ is a stochastic error term.

\section{Data Analysis, Presentation and Interpretation of Results}

Table 1. Descriptive statistics

\begin{tabular}{lcccccc}
\hline & $\begin{array}{c}\text { LAUDIT } \\
\text { FEE }\end{array}$ & BS & BI & BD & ROA & FZS \\
\hline Mean & 12.219 & 14.243 & 0.581 & 6.229 & 0.018 & 21.039 \\
\hline Median & 12.207 & 15.000 & 0.571 & 5.5000 & 0.015 & 21.092 \\
\hline Maximum & 13.508 & 20.000 & 0.895 & 11.000 & 0.120 & 22.440 \\
\hline Minimum & 11.290 & 7.000 & 0.455 & 4.000 & -0.056 & 17.876 \\
\hline Std. dev. & 0.597 & 2.820 & 0.089 & 2.001 & 0.022 & 0.918 \\
\hline Skewness & -0.067 & -0.336 & 1.628 & 0.895 & 1.002 & -0.673 \\
\hline Kurtosis & 1.983 & 2.982 & 6.134 & 2.944 & 10.199 & 3.454 \\
\hline Jarque-Bera & 3.068 & 1.315 & 59.565 & 9.364 & 162.872 & 5.716 \\
\hline Probability & 0.216 & 0.5180 & 0.000 & 0.009 & 0.000 & 0.0574 \\
\hline Sum & 855.295 & 997.000 & 40.654 & 436.000 & 1.257 & 1430.677 \\
\hline Sum Sq. dev. & 24.569 & 548.871 & 0.552 & 276.343 & 0.033 & 56.482 \\
\hline Observations & 70 & 70 & 70 & 70 & 70 & 70 \\
\hline
\end{tabular}

Source: authors' computation (2020) using EViews 9

Table 1 shows the descriptive statistics of the data; the shown audit fees have a mean of 12.220 with corresponding minimum and maximum values of 11.290 and 13.510 respectively. The Jarque-Bera statistics of 3.068(0.2157) implies that the variables are not normally distributed. This may be due to the panel nature of the 
data. Board size is averaged 14.240 with a minimum of 7.000 and a maximum of 20.000. The Jarque-Bera statistics of board size of 1.315(0.518) shows that the variable is not well distributed. Board independence has an average value of 0.581 , implying that $58 \%$ of the directors are independent. It further shows a minimum value of 0.455 and a maximum of 0.85 . The Jarque-Bera statistics of 59.565(0.000) means that the variable is normally distributed. Board diligence is averaged 6.229 with a minimum of 4.000 and a maximum of 11.000. The Jarque-Bera statistics of 9.364 (0.009) shows that the variable is normally distributed. Profitability (measured by ROA) is averaged 0.018 with a corresponding mean of -0.056 and a maximum of 0.120. The Jarque-Bera statistics of $162.872(0.000)$ shows that the variable is normally distributed. Finally, size is averaged 21.039 with a minimum value of 17.876 and a maximum of 22.440. The Jarque-Bera statistics of 5.716(0.057) means that the variable is normally distributed.

Table 2 below displays the correlation analysis, which shows the association between the variables. Board size has a negative correlation of 0.040 ; board independence, board diligence, profitability, and size have a positive relationship of $0.041,0.046,0.454$, and 0.856 respectively.

Table 2. Correlation matrices

\begin{tabular}{lcccccc}
\hline & AUDF & BS & BI & BD & ROA & SIZE \\
\hline AUDF & 1.000 & & & & & \\
\hline BS & -0.040 & 1.000 & & & & \\
\hline BI & 0.041 & -0.063 & 1.000 & & & \\
\hline BD & 0.046 & 0.161 & 0.088 & 1.000 & & \\
\hline ROA & 0.454 & 0.016 & -0.022 & -0.150 & 1.000 & \\
\hline FZS & 0.856 & 0.126 & 0.111 & 0.219 & 0.171 & 1.000 \\
\hline
\end{tabular}

Table 3 displays the results of the GMM (i.e. Generalized Method of Moment). BS is negative and insignificant. This result is in tandem with our expectations. The implication of the finding is that larger boards may have less agency problems and thus require lower audit quality and effort, which invariably reduces audit fees. Board independence has a positive but insignificant influence on audit fees. Independent directors are more concerned with financial reporting quality and may therefore demand a high-quality audit firm, which may be associated with high audit fees. Board meetings have a negative but insignificant effect on audit 
fees of Nigerian DBMs. This implies that board activities reduce audit fees. This means that board meeting frequency will facilitate financial reporting reliability and credibility, which will in turn lead to lower work input and less effort, hence lower AUF. Profitability is positive and significant, which implies that profitable banks may want to disclose more information, which in turn increases audit effort and time and thus increase audit fee. Firm size has a positive coefficient, and it is also highly significant. This implies that larger firms are more complex and require more audit attention due to the number of branches that the auditor needs to visit; this in turn increases audit fees. The main finding is that profitability and size are the significant determinants of the audit fees of Nigerian DBMs.

Table 3. GMM analysis for corporate board of directors' attributes and audit fees

\begin{tabular}{|c|c|c|c|c|c|c|}
\hline \multirow[b]{2}{*}{ Regressors } & \multicolumn{2}{|c|}{ Pooled OLS Estimation } & \multicolumn{2}{|c|}{ Fixed Effect } & \multicolumn{2}{|c|}{ Random Effect } \\
\hline & Coeff. & p-val & Coeff. & $\mathrm{p}$-val & Coeff. & p-val \\
\hline Constant & -0.269 & 0.551 & -2.005 & 0.352 & -0.273 & 0.589 \\
\hline $\operatorname{AUDF}(-1)$ & 0.840 & 0.000 & 0.700 & 0.000 & 0.827 & 0.000 \\
\hline BS & -0.006 & 0.274 & -0.005 & 0.526 & -0.007 & 0.234 \\
\hline BI & 0.011 & 0.948 & 0.335 & 0.311 & 0.033 & 0.861 \\
\hline $\mathrm{BM}$ & -0.005 & 0.580 & 0.003 & 0.775 & -0.004 & 0.644 \\
\hline $\mathrm{ROA}$ & 2.104 & 0.052 & 1.570 & 0.295 & 2.119 & 0.064 \\
\hline FZS & 0.113 & 0.033 & 0.264 & 0.077 & 0.121 & 0.037 \\
\hline R-square & 0.972 & & & 0.977 & & 0.963 \\
\hline $\begin{array}{l}\text { Adj. } \\
\text { R-square }\end{array}$ & 0.968 & & & 0.969 & & 0.959 \\
\hline J-stat & 51.000 & & & 42.000 & & 51.000 \\
\hline Prob J-stat & 0.000 & & & 0.000 & & 0.000 \\
\hline $\begin{array}{l}\text { Durbin } \\
\text { Watson }\end{array}$ & 2.035 & & & 2.334 & & 2.007 \\
\hline $\begin{array}{l}\text { Instrument } \\
\text { rank }\end{array}$ & & & & 17 & & 8 \\
\hline $\begin{array}{l}\text { Hausman } \\
\text { Test }\end{array}$ & 5.318 & 6 & 0.504 & & & \\
\hline
\end{tabular}




\section{Discussion and Conclusions}

The main objective of the investigation is to examine the effect of corporate board of directors' attributes on audit fees of Nigerian quoted DBMs. Data of 10 selected DBMs for seven years from 2012 to 2018 were obtained from their annual financial reports. Using (GMM), we found that the main corporate board of directors' variable that increases external audit fee is board independence, while board size and board diligence reduce it. However, the study could not find any of this variable exerting significant effect on audit fees. Our result as to board size having a positive coefficient is in tandem with that of Bozec and Dia (2017) and Jizi and Nehme (2018), who revealed the positive influence of board independence on audit fees. We found board size and board diligence to have a negative influence on audit fees. These findings are in line with our expectation, as a board may be made up of directors with diverse experiences, including the one related to financial expertise, which may lead the preparation of high-quality financial reports that require less audit services and thus reduce audit fees. As to board diligence, the frequency of meetings may suggest quality financial reporting, which also reduces audit fees. This is in tandem with the finding of Farooq et al. (2018). As to the significant direct effect of profitability on audit fee, it is concluded that profitable companies may want to disclose more information about their companies, which invariably increases efforts and by implication audit fees. Results also reveal that firm size positively and significantly influences audit fees. This is so as larger banks are considered to be more complex and to have more branches that the auditor needs to visit. This increases audit efforts and thus warrants higher audit fees.

Most studies on CG and audit fees have mainly focused on developed countries, while the few ones conducted in developing countries, such as Nigeria, have not focused on the banking sector. Arising from this gap, the study examines the corporate board of directors - an integral part of corporate governance - and external audit fees of Nigerian listed deposit money banks. The study found that boards that are dominated by non-executive directors demand high audit quality, which warrants high audit fees. The quest for audit quality by non-executive directors may be due to the fact that the non-executive directors act as a monitoring tool for aligning shareholders' interest with that of the managers. Therefore, in a bid to ensure this alignment of interests, increased controls and audit are required. This in turn may necessitate the engagement of top-rated external audit firms with the associated high audit fees.

Findings from the study provide evidence that Nigerian deposit money banks can protect shareholders' interest through board independence by having more non-executive directors. As our finding suggests that board independence does not only provide effective monitoring tools of top management, but it also ensures that a high-quality auditor is engaged in a bid to improve financial statement reporting quality and credibility. 
On the relationship between board size and board diligence with audit fees, our study provides evidence to suggest that larger board size and higher frequency of board meetings can reduce agency costs such as external audit fees. This implies a substitution effect between board size and board diligence, two major variables of corporate board of directors' attributes on external audit fees.

Findings from our study indicate that firms with larger board size and board diligence have a tendency of enjoying lower external audit fees. Consequently, in order to have lower external audit costs, DMBs are encouraged to consider larger board size and motivated board members with high level of diligence.

Despite the contributions of this study to the extant body of knowledge, specifically relating to the literature on firms' corporate board of directors, attributes and external audit fees, it is worth mentioning that our study is not without limitations. First, our study examined corporate board of directors' attributes and audit fees of Nigerian DBMs. In order to have broadened perspectives on these concepts, there is a need to explore further sectors as well such as telecommunication, agriculture, oil and gas, manufacturing, etc. Second, the inclusion of other CG variables (such as ownership structure, audit committee attributes, and audit firm size) into the model adopted for the study is likely to produce a more robust study and stimulating findings.

\section{References}

Akhidime, A. (2015). Board structure, corporate characteristics and audit quality of Nigeria banks. International Journal of Economics, Commerce and Management 3(6): 832-846.

Ananthanarayanan, U. (2018). Do corporate governance measures impact audit pricing of smaller firms? Evidence from the United States and New Zealand. The International Journal of Business and Finance Research 12(2): 77-94.

Barroso, R.; Ali, C. B.; Lesage, C. (2018). Blockholders' ownership and audit fees: The impact of the corporate governance model. European Accounting Review 27(1): 149-172.

Bozec, R.; Dia, M. (2017). Monitoring function of the board and audit fees: Contingent upon ownership concentration. International Journal of Accounting $\mathcal{E}$ Information Management 25(1): 70-90.

Carcello, J.; Neal, T. (2000). Audit committee characteristics and auditor reporting. The Accounting Review 75(4): 453-467.

Dabor, A. O.; Dabor, E. L. (2015). Audit committee characteristics, board characteristics and financial reporting quality in Nigeria. International Journal of Economics, Commerce and Management 3(11): 1292-1304. 
Desender, K. A.; Aguilera, R. V.; Crespi, R.; García-Cestona, M. (2013). When does ownership matter? Board characteristics and behavior. Strategic Management Journal 34(7): 823-842.

Effiezal, A. A.; Mazlina, M. Z.; Kieran, J. (2011). Audit fees in Malaysia: Does corporate governance matter? Asian Academy of Management Journal of Accounting and Finance 7(1): 1-27.

Ejeagbasi, G. E.; Nweze, A. U.; Ezeh, E. C.; Nze, D. O. (2015). Corporate governance and audit quality in Nigeria: Evidence from the banking industry. European Journal of Accounting, Auditing and Finance Research 5(1): 18-39.

Ezinando, E. E. E. (2020). Determinants of external audit fees: An empirical analysis of deposit money banks in Nigeria. International Journal of Advanced Academic Research (Social and Management Sciences) 6(3): 1-13.

Farooq, M. U.; Kazim, I.; Usman, M.; Latif, M. I. (2018). Corporate governance and audit fees: Evidence from a developing country. Pakistan Journal of Commerce and Social Sciences 12(1): 94-110.

Ghafran, C.; O’Sullivan, N. (2017). The impact of audit committee expertise on audit quality: Evidence from UK audit fees. The British Accounting Review 49(6): 578-593.

Hicks, J. (1969). A theory of economic history. Vol. 9. Oxford: Oxford University Press.

Ilaboya, O. J.; Iyafekhe, C. (2014). Corporate governance and audit report lag in Nigeria. International Journal of Humanities and Social Science 4(13): 172-180.

Ilaboya, O. J.; Obaretin, O. (2015). Board characteristics and firm performance: Evidence from Nigerian quoted companies. Academic Journal of Interdisciplinary Studies 4(1): 283.

Jensen, M. C. (1993). The modern industrial revolution, exit, and the failure of internal control systems. Journal of Finance 48(3): 831-880.

Jensen, M. C.; Mecling, W. H. (1976). Theory of the firm: Managerial behavior, agency costs and ownership structure. Journal of Financial Economics 3(4): 305-360.

Jizi, M.; Nehme, R. (2018). Board monitoring and audit fees: The moderating role of CEO/chair dual roles. Managerial Auditing Journal 33(2): 217-243.

Karim, K.; Robin, A.; Suh, S. (2015). Board structure and audit committee monitoring effects of audit committee monitoring incentives and board entrenchment on audit fees. Journal of Accounting, Auditing $\mathcal{E}$ Finance 31(2): 248-276.

Kee, H. O. (2015). The impact of audit committee on audit fees in Malaysian publiclisted companies. Malaysian Accounting Review 14(2): 29-53.

Kikhia, H. Y. (2014). Board characteristics, audit committee characteristics, and audit fees: Evidence from Jordan. International Business Research 7(12): 98-110.

Kim, I.; Emma-Riikka, M.; Per, C. T. (2018). Banks' audit committees, audit firm alumni and fees paid to audit firm. Managerial Auditing Journal 34(7): 783-807. 
Kurawa, J. M.; Garba, S. (2014). An evaluation of the effect of credit risk management (CRM) on the profitability of Nigerian banks. Journal of Modern Accounting and Auditing 10(1): 104-132.

Lara, J. M. G.; Osma, B. G.; Penalva, F. (2009). Accounting conservatism and corporate governance. Review of Accounting Studies 14(1): 161-201.

Larcker, D.; Tayan, B. (2015). Corporate governance matters: A closer look at organizational choices and their consequences. Pearson Education.

Leventis, S.; Weetman, P.; Caramanis, C. (2005). Determinants of audit report lag: Some evidence from the Athens Stock Exchange. International Journal of Auditing 9(1): 45-48.

Lipton, M.; Lorsch, J. (1992). A modest proposal for improved corporate governance. The Business Lawyer 48(1): 59-77.

Liu, S. H. (2017). An empirical study: Auditors' characteristics and audit fee. Open Journal of Accounting 6: 52-70. https://doi.org/10.4236/ojacct.2017.62005.

Mallin, C. A. (ed.). (2011). Handbook on international corporate governance: Country analyses. Edward Elgar Publishing.

Mitra, S.; Jaggi, B.; Al-Hayale, T. (2019). Managerial overconfidence, ability, firm governance and audit fees. Review of Quantitative Finance and Accounting 52(3): 841-870.

Monsuru, A. F. (2014). Audit pricing in Nigerian banking industry: A panel analysis (2008-2012). IOSR Journal of Economics and Finance 2(6): 26-34.

Ndebbio, J. E. U. (2004). Financial deepening, economic growth and development: Evidence from selected sub-Saharan African Countries.

O'Sullivan, N. (2000). The impact of board composition and ownership on audit quality: Evidence from large UK companies. British Accounting Review 32(4): 397-414.

Ozkan, N. (2007). CEO compensation and firm performance: An empirical investigation of UK panel data. Electronic copy available at: http://ssrn.com/ abstract $=1102703$.

Salau, A. O.; Ayoib, C. A. (2016). Boardroom diversity and audit fees: Director ethnicity, independence and nationality. Audit Financier 14(4): 413-423.

Soyemi, K. A. (2020). Internal corporate governance practices and choice of external auditor in Nigeria: A logistic regression analysis. Binus Business Review 11(1): 9-16. https://doi.org/10.21512/bbr.v11i1.5894.

Soyemi, K. A.; Sanyaolu, W. A.; Salawu, R. O. (2019). Corporate governance practices and external auditor' reporting lag in Nigeria. Accounting and Taxation Review 3(4): 15-31.

Vafeas, N. (1999). Board meeting frequency and firm performance. Journal of Financial Economics 53(1): 113-142. 
Wu, X. (2012). Corporate governance and audit fees: Evidence from companies listed on the Shanghai Stock Exchange. China Journal of Accounting Research 5: 321-342.

Yaqub, O. J.; Omobitan, A. O. (2012). Impact of deregulation on financial sector development in Nigeria. International Journal of Development and Management Review 7(1): 244-256.

Ye, X. (2020). Literature review on influencing factors of audit fees. Modern Economy 11: 249-260. https://doi.org/10.4236/me.2020.112022.

Zaman, M.; Hudaib, M.; Haniffa, R. (2011). Corporate governance quality, audit fees and non-audit services fees. Journal of Business Finance and Accounting 38(1-2): 165-197. http://dx.doi.org/10.1111/j.1468-5957.2010. 02224.x. 